\title{
Włodzimierz Anioł
}

Institute of Social Policy, Faculty of Political Science and International Studies, University of Warsaw ${ }^{1}$

\section{Quality of life and public space in the processes of urban renewal-selected concepts and debate topics}

\begin{abstract}
Summary
The aim of the article is to show the relationship between the aspirations to improve the quality of life and improve social relations and the undertakings serving the renovation of urban spaces. In the first part of the text-after formulating more general remarks about the social significance of space-a few of the concepts of town modernization implemented in the modern history of the developed world (Cerdá, Haussmann, Le Corbusier) are presented, while pointing out their most often ambivalent social results. Attention to the latter has been paid by, among others, critics of modernism and supporters of alternative visions (Jacobs, representatives of the new urbanism, advocates of the ideas of a socially cohesive or fair-shared city, etc.). As the national empirical illustration, the author then characterizes the case of urban and social changes taking place in the last two decades in the Powiśle district of Warsaw. Their effect, regardless of the general benefits of modernization and the desired and long-awaited approximation of the capital to the river, are also controversial, often critically evaluated gentrification processes.
\end{abstract}

Key words: public space, quality of life, urban policy and renewal, gentrification

1 Instytut Polityki Społecznej, Wydział Nauk Politycznych i Studiów Międzynarodowych UW, ul. Nowy Świat 67, 00-927 Warszawa; author's email address: waniol@uw.edu.pl, ORCID 0000-0003-0929-292X. 
If the space in which people live, work and spend their free time is neglected or inadequately managed, it often generates or exacerbates many significant problems which fall into the domain of social policy. Such problems are not limited to issues related to housing and everyday transport opportunities and include also matters concerning society's health, distribution and availability of facilities providing social services, and conditions for conducting economic and cultural activities, as well as the impact of the surroundings on personal safety, bringing up children and functioning of families, wider groups and communities. Simply put, chaos and spatial disarray considerably reduce the quality of life and significantly increase its cost. This interdependence is noticeable in the case of ecological damages (e.g. air pollution whose level is dangerous to people's health) which result from errors made at the stage of planning the settlement network or even from lack of such planning, in unnecessary expenses incurred due to depreciation of infrastructure which has been built at an unnecessarily large scale, or in adverse side effects of imperfect renewal projects implemented in many cities across the world, which are sometimes collectively referred to as gentrification.

Considered from a more general point of view, space, as is well known, constitutes one of the key determinants and reference points for human life, with time being her only equal in this category. Thus, the shape of space affects human thinking and behaviour. For example, a change of the current natural environment can inspire and generate new ideas, and make it easier to create associations between different facts which can be sometimes very distant from one another. There are landscapes that overwhelm and incapacitate people, and landscapes which provide a boost of energy and can function as important stimuli triggering positive emotions or encouraging deeper reflection. Open space often broadens mental horizons and sharpens reflection, whereas enclosed space can have the opposite effect: it seems to induce claustrophobic reactions and moods, and not only in purely psychological and medical sense.

\section{Social significance of space}

Deliberately organised and arranged physical space reflects social relations, but also shapes them, encouraging people to take certain actions and often provoking specific behaviours. This fact has been known at least since the times of King Arthur when this legendary leader of the Celtic Britons introduced the world to his famous round table-a space designed to eliminate hierarchical differences between the knights, guarantee equal treatment, and enforce equality and partner-like relations between individuals. In more modern and prosaic terms, the presence of benches in contemporary urban spaces shows how seemingly trivial things can affect our everyday lives. Their role is not purely decorative and goes beyond serving as a short-term practical solution for random passers-by who want to rest for a while or use it as site of their leisure activities. The benches serve also a wider social purpose, because they can, for example, 
be a condition determining the mobility or lack thereof of a certain category of residents. If there are no benches in the immediate vicinity, the elderly or sick people who live in a given place may not be able to leave the house. The very design of the bench, its location and lighting can also foster or hinder interpersonal interactions.

Architecture and urban planning are the most important direct tools and methods of creating space. It is worth remembering that the role of architecture does not boil down to forming structures closed by four or more walls. An architectural work is meant to have an impact - to give rise to a new life within a given building, and to affect its surroundings to function in a different way; for example, the area can acquire value which was previously absent and gain certain prestige. ${ }^{2}$ Each and every existing urban layout or architectural design constitutes a specific image of the world, just like scenography in the theatre; it is an interpretation. The defined shape of the urban space either reflects the current state of society and the condition of the state like a mirror, or constitutes a conscious projection of social reality, i.e. is a deliberate attempt to outline a vision of the future and express the expected or desired state of affairs.

The conviction that architecture and urban planning can positively (or negatively) shape people and their lives, and at the same time our entire world, is not an uncommon one (Montgomery, 2016). Although they are seemingly prosaic objects, buildings are believed to be one of the important means of improving both people and society. In any case, the present and future quality of life of citizens is to be to a large extent dependent on the shape of their surroundings and public space. It is not by accident that attention is drawn to the existence of numerous interdependencies and analogies between relations of politics and spatial order and politics and social order, or in other words, between the physical (material) and social (symbolic) dimension of the public sphere (Aniol, 2016, 2017, 2018).

Anyway, if we were to speak about urban space with greater specificity, then buildings, communication routes, green areas, fences or billboards say a lot not only about their creators and investors, but also about their users or recipients. They testify to the intentions and ambitions of their designers, display aspirations, capabilities and possible agency of city authorities, developers and other decision-making entities, but also express more or less conscious preferences of the local residents. Urban space is an expression of the binding regulations, market mechanisms, interests of various groups, existing social structure and its dominant divisions, and the strength of interpersonal bonds, etc.

Diversity within this scope can be illustrated by taking a closer look at, for example, two different models of ancient city centres. The Greek ideal of polis envisaged the agora as a central place which was accessible to all citizens - the focus point of the entire public sphere of that era. It was the site of gatherings, court hearings, political debates, and, with time, also of trade activities. Administrative buildings and temples were also located in the vicinity of this square. On the other hand, Roman cities and settlements were planned

2 This phenomena can be illustrated with the case of the Centre Georges Pompidou which was completed in 1977 in what was then a much neglected district of Paris, or the famous Guggenheim Museum from 1997, which ennobled and completely changed the Spanish city of Bilbao. 
in a different way. They were modelled upon the layout of a military camp (castrum romanum), in the middle of which two roads - cardo (north-south axis) and decumanus maximus (east-west axis, with the line of the road following the sun)-intersected perpendicularly. Let us note, by the way, that the main streets of many European cities are nowadays still mirroring the lines which have been set forth in antiquity. The intersection of these two roads was the place where the Roman Forum was usually located, with the most important public buildings, such as temples, basilicas, baths and amphitheatres, also constructed nearby. Compared with the Athenian agora, the Roman Forum was more orderly-shaped and constituted a space which was a stronger symbol of power of the empire, especially the emperor, and the strength of the entire empire in general. ${ }^{3}$

Leaving ancient states aside, it is also worth noting that the architectural assumptions of the designs of university campuses are also very deliberate. The European model from its very conception assumed that all of the architecture and urban planning, including buildings, would focus around the main courtyard, where paths of lecturers and students of different faculties would intersect with each other. ${ }^{4}$ This peculiar academic microcosm was supposed to facilitate contacts and foster conversations and discussions, in much the same way as it happened in medieval monastery schools which had been built on a plan of a square with a garth in the centre. The tradition of stimulating communication and social relations (here with the intention of stimulating an invigorating, interdisciplinary exchange of ideas, also in the following pattern: professor/teacher-student/pupil) with the help of appropriate organization of physical space is therefore very old. It is respected by the overwhelming majority of contemporary planners who agree that common spaces must be designed in such a way as to maximise their role in generating social interactions.

\section{Cerdá, Haussmann, Le Corbusier-pioneers of the modern urban renewal}

Taking broadly-understood public interest into proper consideration in the design, arrangement and management of urban space has become an important challenge, especially in recent years. A Spaniard, Ildefonso Cerdá (1815-1876), is considered to be the precursor of modern visions of urban development. This father of urban planning and architectural theoretician was also an engineer, a politician and the person who in the mid-nineteenth century created an innovative design of one of the districts of Barcelona (Eixample). The spatial arrangement consisted in a regular network of wide streets with squares, contrasted with green courtyards isolated from the noise of the city and located in the middle of urban quarters - all in order to provide residents with the best living conditions, hygiene standards, more comfortable relations with neighbours and most convenient layout of transport connections.

3 To read more about the way in which various powers and authorities have used architecture (from ancient emperors to modern dictators) and about buildings as emanations of power and strength in a historical perspective, see Sudjic 2015.

4 The American version of the campus looks a bit different-more like an elegant, friendly park with pavilions which are not coincidentally scattered around it in a more or less thought-out way. 
At more or less the same time, France's capital city became the stage of a modernization project of a much larger scale, but also of more debatable consequences. Operating under the political patronage of Louis Bonaparte, Baron Georges-Eugène Haussmann (1809-1891), then the prefect of the Seine Department, managed to change Paris completely in the first two decades of the second half of the nineteenth century. In a city which until that point had been dominated by chaotic and unimpressive medieval buildings, Haussmann decided to build $140 \mathrm{~km}$ of new streets, including wide arteries with boulevards which traversed the city radially, new roundabouts, squares and public buildings, and foremost - the magnificent opera house. He rebuilt the bridges, doubled the number of street lamps and trees, and installed the water and sewage system which was exemplary for that time. In order to build thousands of modern, seven-storey tenement houses, Haussmann ordered demolition of nearly 30,000 existing buildings and hovels, which meant displacement of 350,000 people from lower social classes, i.e. about one-fifth of the inhabitants of Paris.

Therefore, this modernization had its prize-one which was not fully financial, although the original estimated costs of the work were exceeded several times over. Victor Hugo and Charles Baudelaire were among those who protested against the destruction of the old districts of the city, while Haussmann himself finalised his mission among the growing mountain of accusations and was finally forced to leave his post in disgrace. The ambivalent effects of this reconstruction project, and its very Janus-facedness, are emphasised to this day. Its aim was to make the city more modern, worldly, clean and transparent, but the plan assumed that the working class would be pushed out of the centre to the peripheries of the city. As was pointed out in some interpretations-this last goal was also to be reinforced by the political intention to limit the "spatial potential" for grassroots and plebeian social rebellions against the authorities that represented foremost the interests of the elite. One should note, however, that the radical widening of the streets did not prevent building of the barricades during the popular uprising of the Paris Commune in 1871.

A contemporary researcher from Cambridge University, Andy Merrifield, refers to this very historic model of transformation of the Parisian urban fabric, when he labels those of the recent metropolis modernisation projects that privilege the wealthy and bring injury and marginalisation to the poorer groups as examples of "neo-Haussmannization". These are undertakings that lead to appropriation of public resources by the richest, big business and market entities, for example through the mass sale of urban lands or privatisation of municipal companies. Fencing, commercialisation and privatisation of cities in contemporary world of neoliberal post-industrial capitalism remind Merrifield of the process of gating or appropriation of communal rural lands which took place two hundred years ago, at the early stage of industrial capitalism (Merrifield, 2016).

In the 1920s and 1930s, modernism proposed a certain revolution in designing urban spaces and conceptualising architecture and urban planning in general. It constituted a radical break with traditional models dominating in these areas. As believers in the cult of utopian modernity, the creators and promoters of modernism formulated and promoted a number of noble slogans and postulates which concerned also the process of 
shaping, as they put it, "a new space for a new man". The famous Swiss-French painter, sculptor, architect and urbanist, Le Corbusier, who lived in 1887-1965 (and whose real name was Charles Édouard Jeanneret), is commonly recognised as the founding father of this new way of thinking.

The Athens Charter of 1933 - the manifesto of modernism whose development was initiated by Le Corbusier-listed the following three elements as the basic principles of modern architecture: sun, space, and vegetation. The Charter includes statements on the necessity of creating space that will serve people and improve their living conditions; one in which they will be really happy-it was seen as a necessity after a long period of neglecting the housing situation and condemning the vast majority of population to lives spent in shabby homes (in rural huts or in urban shanty towns). These declarations echo some quite clearly leftist-egalitarian beliefs: the city is supposed to be better for everyone, apartments should be cheap, which could be achieved in practice through development of housing co-operatives and public housing, making it easier to obtain land from local governments, offering advantageous state loans, etc.

Le Corbusier argued that glass walls of houses should let sunlight into every corner of flats. Letting light and fresh air into rooms, and ensuring that they have south-facing windows, especially in the case of living rooms, was also justified by health objectives. Good quantity of sunlight and proper ventilation were considered to be remedies for various diseases, including tuberculosis which was still incurable in the interwar period.

Scandinavian modernism, including its leading representative, a Finnish architect, Alvar Aalto (1898-1976), placed the greatest emphasis on maintaining connection with nature and constructing buildings among greenery. Aalto was, for example, the author of the design of the famous sanatorium in Paimio (1933), which was clearly inspired by the principle of "healthy body in a healthy home", which Aalto both professed and promoted. The artist tightly integrated his buildings with their natural surroundings and used the most natural materials, such as wood or stone, both on the inside and the outside. Thus, Scandinavian architects gave modernism a more human, warm, delicate and natureloving face.

All modernists believed in certain common ideals: minimalism, moderation, and functionalist simplicity of solutions-rejection of unnecessary forms, decorations and ornaments. Geometric shapes, flat roofs, and façades deprived of ornamentation were the preferred elements of this architectural style. The "less is more" rule was especially strongly promoted by another guru of modernists, Ludwig Mies van der Rohe (1886-1969), who after leaving Germany in 1937 continued his work in the USA, trying to combine the reductionistic logic of Bauhaus with American technology.

The modernist idea of revolution through urbanism, i.e. the concept of reforming social relations through the reconstruction of the material world, also gained good traction in the USA. After all, this motif was noticeable in the States as early as in the nineteenth century in the flourishing development of a literary genre known as the American utopian novel. Similar thoughts could be detected in an even more complete and clear version 
in the intellectual life of the United States in the first decades of the twentieth century, especially within the so-called Progressive Movement, which was founded i.a. by Thorstein Veblen, an economist and sociologist, John Dewey, a philosopher, and Charles Beard, a historian, first at the University of Chicago and then at the New School for Social Research in New York which they all co-founded. With some pompousness, Beard wrote the following in 1934: "The next America would be a collectivist democracy-a workers' republic —one vast park of fields, forests, mountains, lakes, rivers, roads, decentralised communities, farms, ranches, and irrigated deserts (...) a beautiful country-homes beautiful; communities and farms beautiful, stores and workshops beautiful" (quoted in Graham, 2016, pp. 163-164).

Thus, American Progressives shared with the modernists and their visionary leader, Le Corbusier, the same idea of building a new order—both social and spatial-by means of determining the shape of human settlements. In both cases, the desire was for a radical, even revolutionary change of the existing status, for a break with the past and going through the social life with a plough. Both doctrines had in common the belief that the postulated higher quality of life of residents and citizens should be based on both improved aesthetic qualities of the surroundings and greater functionality of the proposed solutions.

Modernism became a very important driver in the development of active urban policy, including multi-faceted and comprehensive renewal projects. Corbusier-like assumptions were also reflected in initiatives carried out in many cities across the world. The topdown and quite brutal interventions in the urban space became a universal tendency, independent of the ideological underpinnings and affiliations of particular members of municipal authorities. Active municipal public policy became the domain of not only leftwing local government officials and activists, but also right-wing activists, politicians and officials. This can be illustrated by the fact that during re-evaluations conducted in the aftermath of the Great Depression, even the Republican Mayor of New York, Fiorello La Guardia (who held this post in 1934-45), decided that it was worth it to, for example, conduct a public takeover and unification of all subway lines of the city.

In the immediate post-war period, a great modernist renewal programme was undertaken in New York by Robert Moses, a well-known builder of the city. He wanted to demolish entire quarters of narrow streets, located in Manhattan and other areas (some of which were first planned by the Dutch), in order to create new multi-lane flyovers, high-rise office buildings, parks and municipal housing estates (Zipp, 2010). This plan was consistent with the urban planning philosophy and the dominant tendencies of the post-war modernism which considered segregation-avoidance of combining or mixing different functions of the city-to be one of its central principles. Le Corbusier clearly distinguished between four distinct urban "functional zones": business (industrial, office), commercial, residential, and recreational. He favoured separating the zones from each other, just as he advocated for rigorous separation of road traffic (motor vehicles) from pedestrian traffic, in order to achieve greater functionality and convenience. 


\section{Criticism of modernist visions, New Urbanism and other alternative concepts}

It turned out that, in practice, the actual effects of the projects undertaken under the banner of the modernist-style renewal of American cities have often gone wide off the mark when it came to achieving their stated goals. Demolitions significantly reduced housing stock and raised prices of those flats that remained standing, incidentally, in violation of the housing act of 1949, while the highways running through the cities cut off residents of particular districts from others. The too wide streets spelt death to the urban life. Gigantic and impersonal housing estates were often neglected by the authorities and quickly declined, becoming sites marked by high level of crime and unemployment, transforming into infamous symbols of racial segregation. These problems were further exacerbated by a large-scale outflow of more well-off residents to the suburbs, that is, beyond the municipal boundaries, which had a negative impact on the cities' tax revenues and consequently the scope and quality of public services (education, health care, road, sanitation and energy infrastructure etc.). The 1972 decision to demolish Pruitt-Igoe, public high-rise buildings located in Saint Louis, Missouri, which had been built only 17 years earlier, became an iconic proof that this and similar urban renewal programmes were at least partially a failure. Perhaps it was a good thing that the project proposed by Le Corbusier was not finally realised, considering it was based on the idea of demolishing a large fragment of the centre of Paris to set up a complex of 40-storey blocks of flats.

In 1958, Jane Jacobs wrote an article titled "Downtown is for People" which constituted a full-frontal attack on the post-war modernisation investment projects conducted in the US metropolises, including those proposed by Moses in New York. Later, Jacobs expanded her arguments in the famous book of 1961 Death and Life of America's Great Cities (Jacobs, 1993), which has since then been repeatedly reprinted all around the world, and which was first published in Poland only in 2014. Jacobs claimed that traffic jams, noise and other adverse social consequences of the afore-mentioned investment projects overshadowed their public benefits. Strongly criticising Le Corbusier's modernist visions, she argued that the cities created in accordance with the modernist ideals would be, in her words, "stable, symmetrical and orderly. They will be clean, impressive and monumental. They will have all the attributes of a well-kept, dignified cemetery (...) These projects will not revitalize the downtown, they will deaden it" (Jacobs, 2012, pp. 115-116).

Jacobs herself postulated creation of compact settlements with a more human, intimate scale and diverse functions. She believed that they should arise in an organic and spontaneous way, and should not be the result of top-down planning and some sort of gigantomania. She advocated for intertwining and mixing functions of urban life, instead of separating them from each other, which meant that shops, flats, recreation areas and workplaces were to be directly adjacent to each other. She argued that the segregation of residents' lives into "unconnected atoms" disintegrates the city.

Streets and sidewalks were, according to her, the "most important organs" and binding elements of the city. The streets are primarily the site where city residents come in contact 
with shopkeepers, newsagents or other clients in a bakery; everyday life is carried out at a small scale at street level, shaping a sense of trust and security, and giving rise to awareness of having "public identity (...) and public respect". Therefore, planners should, above all, support "lively and interesting streets", which should remain the domain of pedestrians, not cars. They are a source of diversity and an opportunity for frequent meetings between people, even strangers.

In the 1960s, critical opinions about modernist urbanism became more common. Its critics claimed that modernism deprives cities of human proportions, destroys their tissue, concentrates too much on buildings, and negates the historical identity of places, as it ignores classical relations and systems developed over centuries in the urban space: streets, squares, and districts. As it turned out and was increasingly often emphasised in public discussions, modern cities age much faster than traditional cities, while the latter adapt much easier to new challenges and changing needs of their residents.

The criticism of modernism in relation to architecture and urban planning became even more radical in 1980s and 1990s, when the entire philosophy was negated globally during the rise of post-modernist tendencies. The end of the 20th century coincided in the United States with the dawn of a new ideological movement and trend in urban planning called New Urbanism. Within the framework of this ideology, many people began to advocate restoring cities to human scale, recommending in essence a return to traditional methods of urban organisation, including more clear definition of boundaries between public and private space (Katz, 1994). The public sphere gained primacy in this doctrine-it was decided that the private sector's interests and market processes should never override it. The emphasis was placed on the reconstruction of common spaces and social bonds in communities of neighbours (see Świątkowska, 2014). Other widely-popularised theories turned out to have a lot in common with this way of thinking-e.g. the compact city theory, or concepts of a socially cohesive city, fair-shared city, and a smart city (the last one being the newest notion).

Jan Gehl, a famous Danish architect and urban planner, has long been developing and promoting the idea of improving urban space in such a way as to make it more citizen-friendly (Gehl, 2014). In his opinion, urban space should be planned from the perspective of a pedestrian and a cyclist, not a driver or a tenant of a skyscraper, because life necessarily takes place, or even thrives, in spaces between buildings. The vision of a walkable city restores the primacy of walking people and requires overcoming the dominance of vehicular traffic, especially in city centres. Adoption of this vision as an objective leads to such practical actions as: narrowing streets in city centres, introducing bans on entry and parking in specific zones, making walking routes wider, hiding thoroughfares, which painfully divide city quarters or separate them from such elements of the city as a river, in underground tunnels (see, for example, the section of the Warsaw's thoroughfare, Wisłostrada, which was hidden inside a tunnel in Powiśle district, which will be discussed in greater detail below). It includes also special paths for cyclists, rollers and runners, which in the US are called pleasureways or greenways. 
A separate, but at the same time complementary course of action is the emphasis on environmental and landscape protection, introducing "green implants" (biotopes) into the urban space or organisms, not only on streets or squares, but also on roofs and façades of houses. Any environment which is friendly and full of greenery makes people feel more secure, happier, and healthier, and helps them stay active longer. Such a green environment encourages greater mobility-leaving one's home, engaging in physical movement and establishing relationships with other people. Psychological research shows that people are less stressed in places filled with trees and shrubs.

The above-indicated tendencies are accompanied by the second, i.e. the latest, phase or version of urban renewals (the first was the one associated with the modernist projects) which can be recently observed all over the world, especially in the West, including the USA. The dilapidated centres of large agglomerations, including degraded and impoverished post-industrial districts, are starting to arouse the interest of private investors, municipal authorities and, above all, those who dictate the demand, that is, the members of the middle and upper classes. The latter were previously "led astray", although not by force, but by its own choice, displacing themselves more or less willingly to distant suburbs as part of processes of suburbanisation and the so-called urban sprawl. Meanwhile, the city centre has recently become an attractive living place for medium and highly qualified specialists, in particular, members of the so-called creative class, i.e. specialists associated with creative industries (term coined by Richard Florida-see Florida, 2008). Members of this class show interest in living in trendy post-industrial lofts, in the close vicinity of respectable and well-visited cultural institutions, valuable monuments, snobbish meeting places, good restaurants, etc.

However, the above-described trend and last-generation renewal projects also have their social costs, which are usually referred to collectively as gentrification. This term refers to a process in which wealthier and dynamic new residents-at first, they are usually freelancers and younger people-begin to flock into a renovated district and start forcing out the poorer, and generally older residents who have lived there longer. ${ }^{5}$ The older residents who have strong roots in the place start feeling increasingly uncomfortable, even foreign, in the area and are compelled to move out due to economic factors-primarily due to spikes in rents and prices of goods in shops.

This or a very similar pattern of changes, or a sequence of events, repeats itself in all regions which are undergoing gentrification. At the very beginning, we start with a neglected, degraded, under-invested, often post-industrial area (sometimes the area in question was previously closed to the public_-used by the military or a railway company), but with great potential and attractive location, e.g. in the very centre of the city or very close to city centres.

This is the stage upon which first outposts of gentrificators arrive. Like paratroopers or commandos, they land on the new, virgin territory, explore it, and begin to gradually

5 To read more about gentrification in Polish literature, see Grzeszczak, 2010; Jakóbczyk-Gryszkiewicz, 2012. 
take it over. By "colonizing" this area step by step, they force out traditional practices and forms of relations. Such pioneers include, for example, aspiring artists who want to rent cheap, but large apartments, because they need them for their studios. Students may form another group of such new arrivals, as their numbers are growing in many larger cities due to the general academic boom, which in consequence leads to the so-called "studentification". As a result, the area gains first fashionable small bars, alternative pubs, hip café-clubs, and cult meeting places used for recreation or entertainment purposes.

At the next stage, the space becomes more and more prestigious. Reacting to this new situation, private business invests in real estate and land. The market valorises the area. Due to the pressure exerted by the rising prices and the needs of new residents, cheap stores which served the area's original residents, craft services and bookshops which cannot withstand the rental competition, begin to gradually disappear. In this changing environment, the original residents of the area begin to feel increasingly alienated. Alienated "locals" begin to gradually give way to "urban nomads", also known as "people of the flows".

Finally, a much more expensive material infrastructure appears in the area: luxury apartments and office buildings for the "new urban gentry", shops representing international chains, branches of banks, chain drug stores, delicatessens and pharmacies, and ultimately also cafés, galleries and restaurants addressed to wealthier tourists. The invasion of the latter and the related transformations which take place in the urban public space are sometimes referred to as "touristification". The final results of the outlined sequence of events are even higher rents which employees of corporations, lawyers or doctors can afford, whereas poorer service providers, consumers, as well as oldest tenants do not and are eventually forced out of the area. The pioneers of the whole processyoung members of the creative class and people who work in culture and art and do not earn a lot of money, and students-move out at that point, if they did not manage to buy their apartments in the meantime.

The example of processes which have been changing the image of Warsaw's Powiśle district in the last two decades will be used here to illustrate the changes in urban planning and social relations which are currently on-going within the framework of the urban renewal projects.

\section{Opening Warsaw to the river and gentrification processes in Powiśle}

Warsaw's return to the Vistula river or, in other word, the city's turn towards its river (because it is not ultimately clear whether Warsaw and its river have ever been very closely and intimately connected) is one of the most fundamental and spectacular changes, or even revolutionary upheavals, which have taken place in the public space of Warsaw after 2000. Bringing the Vistula back to the Varsovians, i.e. fulfilling the dream of many, e.g. the pre-war president of Warsaw, Stefan Starzyński, has not only been the flagship policy programme of the capital city's local government authorities and city movements in the last dozen or so years, but also something which the citizens themselves have quite 
unequivocally supported. The Vistula River has recently become another informal district of the city with its own special plenipotentiary in the city hall. On the other hand, Powiśle itself, especially the area of the riverside boulevards, has been gradually transforming into an alternative or complementary "lower-level" representative "salon" of Warsaw, which functions in opposition or as a supplement to the "upper-level" salon, located on the escarpment, on the revitalised Krakowskie Przedmieście street.

In the first half of the 20th century, as in previous centuries, Powiśle was still one of the poorest and most forgotten parts of the city-a place full of crime, robberies, whore houses and rubbish dumps. ${ }^{6}$ After the war, this district, which was as destroyed as other parts of the city and rebuilt in individual spots (in places such as Mariensztat, with great success), remained outside the main interest of the city authorities. Throughout the entire period of the Polish People's Republic, built-up areas were chaotic, lacking a coherent spatial development plan, and especially any underlying notion of using this district to bind the city more closely with the river.

The first investment which brought the city—and especially Powiśle—significantly closer to the river was the new building of the University of Warsaw Library (BUW) located at Dobra Street, which was opened to the public in 1999. It looks like a monumental temple of books and knowledge and is probably the most outstanding architectural work erected in Warsaw in the 1990s. It was designed by Marek Budzyński, a critical modernist whose artistic inspirations were drawn foremost from Scandinavia, where he spent many years of his life. ${ }^{7}$ At the first glance, the most striking element of the library building is its rather harsh finish made of polished concrete and green-patinated copper sheets. The building complements the landscape and surroundings of Powiśle, is environmentally friendly and demonstratively pro-ecological, which is additionally emphasised by plants which grow on the library's façades and the one-hectare garden, with its multiple alleys and benches, located on the building's roof. Thus, the building of the library seems to supplement, recreate and compensate for the space which has been appropriated from local residents by this investment, and, at the same time, symbolically illustrates the symbiotic connection between nature, culture and humans.

A roofed street hidden inside the building acts as a large lobby and functions at the same time as a quasi-extension of the city. In a sense, it connects the university community with Warsaw residents and tourists. The fact that a certain academic-urban community has thus been formed may be evidenced by the existence of a phenomenon known as

6 In the late nineteenth century, Bolesław Prus wrote a novel titled Lalka [Doll] whose main character, a romantic businessman, Stanisław Wokulski, at one point strolled through the miserable streets of Powiśle, pondering over ideas and dreams which at that point seemed very utopian: "Warsaw, with all of its enormity, gravitates and slides down towards the Vistula. If the banks were fortified with boulevards, the most beautiful part of the city would be created there: buildings, shops, avenues...". Perhaps we are living in the times when Wokulski's visionary dreams and hopes are starting to come true.

7 Scandinavian inspirations are also visible in Budzyński's other projects—both older ones, such as the Ursynów Północny neighbourhood created in the 1970s, and newer ones, e.g. the Podlasie Opera and Philharmonic-European Centre for the Arts in Białystok which was built in 2012. 
"buwing" (which refers to the abbreviated name of the library-BUW), which means visiting, hanging out and spending time in the library for social purposes, especially when it is done by people other than students, researchers or academics. The book collection can be reached by walking from the inner "street" onto a monumental staircase flanked on both sides by colonnades adorned with figures of four great Polish philosophers. Natural light access the building and reaches not only the main reading room, but also many nooks and crannies of the entire three-storey-construction, emphasising its functionality.

The new library was deliberately located in Powiśle by Jan Rutkiewicz, an urban planner and the first mayor of Śródmieście (Warsaw's central borough which includes Powiśle district), who, after the revival of local government in 1990, offered a city-owned plot of land in Powiśle to the university. Rutkiewicz was also the author of the vision of a new bridge which was to be located near the library-the Świętokrzyski bridge. It was imagined as a low-support, local crossing, cut off from the adjacent busy thoroughfare, Wisłostrada, which runs alongside the river and is hidden inside an almost one-kilometrelong tunnel. Exclusion of the transit function of the bridge, as well as the fact that creation of the tunnel meant that a new plot of city-owned land was created above it, affected the development of this part of Powiśle. New investments were implemented within the area, the quality of life of local residents improved (through e.g. reduction of noise and emissions) and, in more general terms, the city "returned" to the river. It is worth noting that this idea was often criticised and derided during its planning and implementation stage. Many asked why the tunnel should run parallel to the river, not under it. It was also argued that one more bridge could be built for the amount of money that was to be spent on the tunnel (PLN 220 million). However, as it turned out, when the tunnel was opened for use in 2003, it physically reconnected Powiśle with the riverbank, from which it had been practically cut off previously by intense car traffic on Wisłostrada.

The first harbingers of public and recreational activity appeared on the riverbank, at the back of the University of Warsaw Library, immediately after the construction of the tunnel. Containers housing the first club located directly on the riverbank appeared in the summer on the so-called "snow platform" (a platform on which snow used to be dumped from containers) - Cud nad Wisłą [Miracle at the Vistula]. This massively crowded place quickly found its followers-more bars, clubs and concert venues began to appear; some of which were organised on barges moored on the river. It can be said that during the holiday season, the focus of Warsaw social life, especially in the eyes of young people, has begun to move to the river.

The fact that the tunnel made it easier for Warsaw residents and tourists to reach the Vistula was also an important factor for the success of the Copernicus Science Centre, irrespective of the value of its original exhibition and offer. Opened in 2010, it is actually the first large facility in the capital city which is located literally on the bank of the river. The curve created by the two wings of the building envelops a planetarium whose broken, rusty structure resembles an erratic boulder. Its immediate surroundings contain more smaller, natural boulders. It is worth noting the symbiosis between the architecture and the natural environment-it is a marriage of culture and nature. Just as in the case of 
BUW, there is a garden on the roof of the Copernicus Centre from which one can observe the river from above. While the older of the gardens is more picturesque, idyllic, and "romantic" in tone, its younger counterpart is more severe and rough, displaying more adequately the brutality of nature. Its surface is riddled with "craters"-glass patios of the lower storeys of the Centre which are filled with wild vegetation or water and let daylight into the building in a very practical way.

The Discovery Park was created around the Centre as an open site hosting experimental sound devices and other exhibits, as well as summer open-air cinema. At the beginning of 2017, the Centre gained a new neighbour-a pavilion of the temporary seat of the Museum of Modern Art, referred to as the Museum on the Vistula. ${ }^{8}$ In the summer months, the popular breakfast market is organised in front of the museum, which allows people to not only buy vegetables, fruit, dairy products and preserves directly from their producers, but also listen to live music, and take part in workshops and theatre meetings.

The city and the river were brought together even more closely, even directly, by the new Vistula boulevards whose successive sections have been gradually opening to the public since 2015. Their first herald was the Multimedia Fountain Park which was created in Podzamcze area. Since 2011, the fountain park has been staging original shows in which the main roles are played by water (which is sprayed or used in the form of streams coming out of 367 nozzles) and light emitted by lasers and multicolour LED reflectors. Glass pavilions with numerous functions were built on the new boulevards, and similar floating facilities were moored at the quay. A small amphitheatre was established near the Copernicus Centre, and sculptures (fish made of concrete) were placed on the boulevards; there is also a water park and space for children. The area surrounding the Mermaid statue has also undergone a thorough renovation.

Luxury apartment buildings were constructed behind the Copernicus Science Centre, in the second line of buildings (Nowe Powiśle housing estate). The renewal of the old Powiśle power plant is still on-going. It is being done in accordance with the design of architects from the APA Wojciechowski studio commissioned by White Star. Once they are renovated and adapted to the new functions, the over-100-year-old halls (which were stripped down to the skeleton during the construction works, which caused serious worries among the fans of the city's history) will become the home of shops, restaurants and cafés. Three office buildings, a luxury apartment building, and a hotel created in an old converted building, will be constructed near the power plant. The space between these buildings will be filled with public squares, small streets and glass covered passages. All of these elements are to form together a multifunctional complex of EC Powiśle.

Additionally, it is worth emphasising that the distance between the left-bank Warsaw and the right-bank Warsaw significantly decreased in the area of Powiśle. Five free ferries make it easier for non-motorised people to get across the river, increasing the access, to e.g. the revitalized beaches of Praga: Rusałka, Poniatówka and Saska. The investment

8 This pavilion, which the Museum of Modern Art received free-of-charge for the period of three years from one of the Viennese foundations, was previously the temporary seat of the Berlin Kunsthalle gallery. 
plans include also a footbridge from Mariensztat to Praga (on the axis of Karowa and Okrzei Streets), intended for both pedestrians and cyclists. The state-of-the-art National Stadium, built for Euro 2012 on the right bank of the Vistula, clearly shifted the city's centre of gravity to the east.

All the above-mentioned new investments, both public and private, radically changed Powiśle. The processes which have been taking place in the last two decades in this area seem to be a good illustration of the Janus-faced nature of modernising urban and social changes taking place in many contemporary cities of the developed world, as well as at the wider scale which concerns the entire society.

On the one hand, the renewal of the district positively impacted the whole area, raising its attractiveness and value. In particular, it became much more multi-functional and accessible (especially in the immediate vicinity of the river) for both Varsovians and tourists. On the other hand, such positive changes were accompanied by a process of "capitalising" on the growing fashion for Powiśle and the model-like gentrification of the district, which, as it has been noted earlier, meant increases of prices and rents in trendy locations, emergence of closed neighbourhoods, multiplication of more expensive restaurants and luxury boutiques, and, at the same time, removal of cheaper service companies from such areas and alienating poorer social groups, including the original residents of the district.

Many inexpensive service providers, including places conducting cultural activities, disappeared in the face of the rent surge, falling under the competitive pressure created by purely commercially-oriented tenants. For example, price competition proved too tough for the four clubs whose history began in the first decade of the new centuryJadłodajnia Filozoficzna, Czarny Lew, Diuna and Aurora-which were all located in one of the courtyards at Dobra Street, and because of the street's name, which in Polish means "good", were collectively called Zagłębie Dobra [Basin of Good]. The courtyard used to be a site of intimate musical concerts, which in the summer months often lasted until dawn, and various cultural and poetic events, such as one-poem contests. At the end of 2015, the local housing cooperative terminated the lease agreement of a cult bookshop Tarabuk which had to close because it was unable to meet the rocketing price expectations of the cooperative. Shortly thereafter, at the beginning of 2016, the legendary and first in Warsaw café bookshop Czuły Barbarzyńca disappeared from the corner of Dobra and Zajęcza streets for the same reasons after 14 years of operations. The bookshop was widely known for many initiatives and socio-cultural events, such as Sunday family book-oriented meetings. It was a significant event signifying the growing trend towards marketization and, in a sense, a symbolic one, because the lease agreement was in this case terminated by the owner of the tenement house who was infamous for buying reprivatisation claims for various Warsaw real properties.

Thus, Powiśle became an illustration of a more universal dilemma and challenge which can be expressed in the following question: how can a given district become modern, fashionable, and open to new social groups, including the creative middle class, and still remain a relatively cheap, egalitarian space, available to everyone, including less 
affluent residents, service providers and consumers? How can valuable relationships and traditional social networks be maintained in the course of modernisation and revitalisation changes? How can we avoid breaking these precious ties unnecessarily? ${ }^{9}$ Is trying to achieve such a state an attempt to square a circle?

\section{Conclusions}

Finally, putting the case of Powiśle aside, it is possible to formulate at least three general conclusions and postulates in response to the challenges posed by gentrification processes in the revitalised parts of large agglomerations.

First of all, it should be acknowledged that spatial order and a specific "culture of space" remain one of the most important features of the desired and expected quality of life in cities, as well as in other, non-urban areas of residence. Public spaces have a particularly important role to play in this context, as their scale and shape determine whether the city can be considered to be, to put it shortly, a "friendly" one for its residents. Counteracting spatial chaos, reinforcing the importance of spatial development planning and fostering its more frequent use are objectives which are constantly repeated in speeches, postulates and recommendations formulated in recent years by international organizations (e.g. UN, European Union), governments or politicians seeking public offices, which was noticeable even during the recent local election campaign which was conducted in Poland before the October 2018 local government elections.

Secondly, when it comes to development processes, it is not worth leaving everything to the free market. We should actively influence the changes taking place in the urban space, consciously shaping the way it functions. When managing modernisation projects, the municipal authorities should reduce the negative effects of gentrification, and mitigate the strong pressure of the market and the private, especially speculative capital. The authorities can use for this purpose such municipal policy instruments as, for example, protecting city-owned flats and supporting social housing development in the districts which are subject to renewal processes. A deliberate rent policy can also help prevent the creation of social ghettos, both the enclaves of poverty and underdevelopment, and the oases of wealth and modernity, and foster development of various urban functions. For example, in Kreuzberg, a district of Berlin, when someone wants to open a new café, the city council sets the rental price on the basis of assessment of the situation and checks, among other things, how many similar places are operating already on a given street, how much coffee is to cost in this new place, and how the planned prices compare to the average earnings in the district, etc.

Thirdly, it is very important to involve residents and civic urban movements in the agglomeration renewal processes. Local government authorities should support the

9 For example, an elderly, ailing resident of a renovated tenement house can be moved from a revitalised district to a nicer and more comfortable flat in another part of the city, but what if a neighbour who supports her on a daily basis moves to a completely different place and the old lady has to be therefore provided with some form of external, institutional social care? 
involvement of local communities in changes, as part of the empowerment formula, through creation of multi-sectoral public-social partnerships, if necessary, also with participation of private-market entities. ${ }^{10}$ Tenant associations or environmental protection organizations also have independent roles to play. As significant pressure groups critical of city authorities, they can exert pressure on their decisions and promote various alternative solutions.

Intellectual foundations for the development of the so-called new urban movements were laid down by Henri Lefebvre, a leftist philosopher and French sociologist, in his famous essay entitled Le droit à la ville, which was published for the first time in 1967 in 6th issue of "L'Homme et la société"11. In this essay, Lefebvre presented revolutionary proposals of the analytical science of the city, combining urban planning with the general theory of urban space-time continuum. He proposed to establish a reformed, grassroots urban policy, based on the achievements of science and art, and seeking new, pro-citizen solutions in relation to, on the one hand, inefficiency of many functions of traditional public policy, and, on the other hand, with increasing expansion of market forces, such as large corporations, financiers, bankers or developers, in urban spaces.

When it comes to more recent times, Lefebvre's ideas are referenced and reinterpreted in a probably even more radical way by David Harvey in his 2012 book entitled Rebel Cities. From the Right to the City to the Urban Revolution (Harvey, 2012). ${ }^{12}$ Its author presents the city and its inhabitants as a new space of social rebellion (previously, the same function was played by factories and workers' associations) and writes about the transformation of the concept of the right to the city into an urban revolution. ${ }^{13}$

\section{References}

Anioł, W. (2016). Kształtowanie przestrzeni miejskiej jako mikrokosmos polityki publicznej. Przypadek Warszawy. Studia z Polityki Publicznej, no. 2 (10).

Anioł, W. (2017). Między starym i nowym. O sposobach modernizowania przestrzeni publicznych. Studia z Polityki Publicznej, no. 2 (14).

Anioł, W. (2018). Metamorfozy domeny publicznej i ich janusowe oblicze społeczne. Studia $z$ Polityki Publicznej, no. 1 (17).

${ }^{10}$ In Poland, real opportunities to get citizens involved in urban renewal processes, e.g. by consulting relevant programmes, are created the Act on Revitalization of 9 October 2015 (entered into force in January 2016).

${ }^{11}$ Polish translation of this text: Lefebvre, 2012. To read a more in-depth discussion of this thinker's ideas, see Butler, 2012.

12 The well-known and widely quoted earlier publications of this author include book titled Social Justice and the City (Oxford 1973) and a pamphlet A Brief History of Neoliberalism (Polish edition: Warsaw 2008).

13 To find out more on the political role of cities and reclaiming of urban space by movements that contest the neoliberal model of capitalism, see also works written by the following Polish authors: Urbański, 2005; Nawratek, 2008. 
Butler, Ch. (2012). Henri Lefebvre: Spatial Politics, Everyday Life, and the Right to the City. New York-London: Routledge.

Florida, R. (2008). Who's Your City? How the Creative Economy is Making Where to Live the Most Important Decision of Your Life. New York: Basic Books.

Gehl, J. (2014). Miasta dla ludzi. Kraków: Wydawnictwo RAM.

Graham, W. (2016). Miasta wyśnione. Siedem wizji urbanistycznych, które ksztattuja nasz świat. Kraków: Karakter.

Grzeszczak, J. (2010). Gentryfikacja osadnictwa. Charakterystyka, rozwój koncepcji badawczej i przegląd wyjaśnień. Warszawa: Instytut Geografii i Przestrzennego Zagospodarowania PAN.

Harvey, D. (2012). Bunt miast. Prawo do miasta i miejska rewolucja. Warszawa: Fundacja Bęc Zmiana.

Jacobs, J. (1993). The Death and Life of Great American Cities. New York-Toronto: Random House.

Jacobs, J. (2012). Śródmieście jest dla ludzi. In: B. Świątkowska (ed.), Chwała miasta. (115-130). Warszawa: Fundacja Bęc Zmiana.

Jakóbczyk-Gryszkiewicz, J. (ed.) (2012). Procesy gentryfikacji w mieście. Vol. I. Łódź: Wydawnictwo Uniwersytetu Łódzkiego.

Katz, P. (ed.) (1994). The New Urbanism: Toward an Architecture of Community. New York: McGraw-Hill.

Lefebvre, H. (2012). Prawo do miasta. Praktyka Teoretyczna, no. 5.

Merrifield, A. (2016). Nowa kwestia miejska. Warszawa: Wydawnictwo Naukowe PWN. Montgomery, Ch. (2016). Miasto szczęśliwe. Jak zmienić nasze życie, zmieniając nasze miasta. Kraków: Wysoki Zamek.

Nawratek, K. (2008). Miasto jako idea polityczna. Kraków: Korporacja Ha!art.

Sudjic, D. (2015). Kompleks gmachu. Architektura wtadzy. Warszawa: Fundacja Centrum Architektury.

Świątkowska, B. (ed.) (2014). My i oni. Przestrzenie wspólne/projektowanie dla wspólnoty. Warszawa: Fundacja Bęc Zmiana.

Urbański, J. (2005). Odzyskać miasto. Samowolne osadnictwo, skłoting, anarchitektura. Poznań: Bractwo Trojka.

Zipp, S. (2010). Manhattan Projects: The Rise and Fall of Urban Renewal in Cold War New York. Oxford: Oxford University Press. 


\section{Jakość życia i przestrzeń publiczna w procesach miejskiej odnowy - wybrane koncepcje $i$ watki debaty}

Streszczenie

Celem artykułu jest pokazanie związków między dążeniami do podniesienia jakości życia i poprawy stosunków społecznych a przedsięwzięciami służącymi odnowie przestrzeni miejskich. W pierwszej części tekstu-po sformułowaniu ogólniejszych uwag na temat społecznego znaczenia przestrzeni-wskazano kilka realizowanych w najnowszej historii rozwiniętego świata koncepcji unowocześniania miast (Cerdà, Haussmann, Le Corbusier), akcentując ich najczęściej ambiwalentne skutki społeczne. Na te ostatnie zwracają uwagę m.in. krytycy modernizmu i zwolennicy wizji wobec niego alternatywnych (Jacobs, przedstawiciele tzw. nowego urbanizmu, promotorzy idei miasta spójnego społecznie, „sprawiedliwie dzielonego” itp.). Tytułem krajowej ilustracji empirycznej, autor scharakteryzował następnie przypadek przemian urbanistycznych i społecznych, jakie zachodzą w ostatnich dwóch dekadach w warszawskiej dzielnicy Powiśle. Ich efektem, niezależnie od generalnych korzyści modernizacyjnych oraz pożądanego i długo oczekiwanego zbliżenia stolicy do rzeki, są także kontrowersyjne, często krytycznie oceniane procesy gentryfikacyjne.

Słowa kluczowe: przestrzeń publiczna, jakość życia, polityka miejska, rewitalizacja, gentryfikacja 